WOJCIECH OSIAL, ŁOWICZ

\title{
KATECHIZM NARZĘDZIEM KATECHEZY - BOGACTWO TRADYCJI WOBEC WYZWAŃ WSPÓŁCZESNOŚCI
}

Temat roli i miejsca katechizmu we współczesnej katechezie nie jest zagadnieniem łatwym do omówienia. $Z$ jednej strony Kościół przypomina o potrzebie katechizmu, $\mathrm{z}$ drugiej zaś zauważamy wiele trudności w jego nauczaniu. Bogactwo tradycji zderza się więc z wyzwaniami czasów współczesnych. Słyszy się też opinie o końcu epoki katechizmu i potrzebie nowej katechezy, zróżnicowanej i szerszej w jej rozumieniu, gdzie katechizm stanowi jedynie jedno z możliwych jej narzędzi. ${ }^{1}$ Katechizm domaga się zatem poważnej refleksji, która określi jego zadania w kontekście aktualnych wyzwań duszpasterskich i katechetycznych.

Podejmowane rozważania to próba włączenia się w poszukiwanie rozwiązania tego ważnego problemu. Refleksja zostanie dokonana w trzech punktach: najpierw nastąpi krótkie spojrzenie w przeszłość ukazujące rolę katechizmu w historii katechezy; następnie zostaną przywołane wskazania zawarte w dokumentach Kościoła; trzecim i ostatnim punktem będzie analiza współczesnych wyzwań pod adresem katechizmu.

Konieczne jest jeszcze jedno wstępne wyjaśnienie. Mówiąc o katechizmie, ma się na uwadze pisemny wykład nauki wiary stanowiący kompendium podstawowej doktryny Kościoła. W takim znaczeniu katechizm ma formę książki i stanowi narzędzie katechetycznego nauczania. Tym samym odróżnia się od wszelkich podręczników katechetycznych czy tekstów dydaktycznych, szczególnie podręczników

E. A $1 \mathrm{~b}$ e $\mathrm{r}$ i c h, La questione del catechismo: uno sguardo al passato e prospettive di avvenire, w: E. A $1 \mathrm{~b}$ e $\mathrm{r}$ i c h, U. G i a n e t t o (red.), Il catechismo ieri e oggi, Leumann, Torino 1987, s. 9. 
do nauki religii, których zadaniem jest pośrednictwo w przekazie prawd wiary zawartych w katechizmach.

\section{Długa tradycja katechizmowego nauczania}

Najbardziej odległe korzenie katechizmu sięgają czasów narodzin Kościoła. Od samego początku katecheza wykazywała potrzebę posiadania jakiegoś narzędzia, które byłoby pomocą w nauczaniu prawd wiary. Wszystkie podejmowane starania katechetyczne były odpowiedzią na tego rodzaju zapotrzebowanie i stworzyły tym samym długi i bogaty proces narodzin i rozwoju katechizmu.

Już w czasach starożytności chrześcijańskiej Kościół formułował pierwszą naukę wiary w postaci różnorodnych formuł i wyznań wiary. W okresie katechumenatu funkcje katechizmowe pełniły formuły Symboli wiary i modlitwy Pater noster. Obok formuł i schematów doktrynalnych należy wymienić także różne pisma patrystyczne. Jakkolwiek nie zawsze możliwe jest precyzyjne oddzielenie ich funkcji katechetycznej od teologicznej, to jednak u niektórych z nich wyraźnie dostrzega się cechy katechizmów. ${ }^{2}$

W średniowieczu funkcjonowały różne pomoce katechetyczne służące nauczaniu ludzi ochrzczonych. Można wskazać na dokumenty synodów lokalnych zawierające syntezy i zestawy prawd wiary, liczne kompendia i sumy katechetyczne, septenaria, elucidaria, podręczniki duszpasterskie, książki spowiednicze, podręczniki życia chrześcijańskiego (zwierciadła). Pod koniec średniowiecza, w XIV w., pojawiają się pierwsze książki, które w swoich tytułach nazywane są już wprost katechizmami. ${ }^{3}$

W XVI w. powstały pierwsze wielkie klasyczne katechizmy. Był to początek ery katechizmu. ${ }^{4}$ Katechizmy stały się głównym

2 Por. W. O s i a 1, Historia katechizmu. Geneza i rozwój katechizmu w Kościele katolickim od I do XVI wieku, Warszawa 2013, s. 27-124.

3 Por. tamże, s. 125-225.

4 Por. R. Mu raw s k i, Geneza i rozwój katechizmu w Kościele katolickim, w: T. P a nús (red.), W co Kościót wierzy i z czego żyje, Kraków 2004, s. 166; 
narzędziem nauczania i tym samym wyznaczały treść katechetycznego przekazu. Można przywołać tutaj katechizmy Erazma z Rotterdamu, Marcina Lutra, św. Piotra Kanizjusza, Katechizm Rzymski, katechizmy E. Augera i św. R. Bellarmina. ${ }^{5}$ Wieki następne to okres dalszej dominacji katechizmów i katechezy doktrynalnej. Stosowano katechizmy już istniejące, szczególnie Kanizjusza i Bellarmina, jak i redagowano nowe, np. katechizm J. Deharba z połowy XIX w. ${ }^{6} \mathrm{Za}-$ sadniczo ich funkcja była ograniczona do przekazu wiedzy. Wynikało to $\mathrm{z}$ faktu, że większość $\mathrm{z}$ nich była zorientowana na walkę z ignorancją religijną i obronę czystości wiary. Były to kompendia doktryny, często abstrakcyjnej i dalekiej od problemów życia człowieka.

Dominacja katechizmów doktrynalnych ustała dopiero wraz $\mathrm{z}$ narodzinami odnowy kerygmatycznej w połowie XX w., kiedy poddano krytyce dotychczasowy sposób nauczania i zwrócono się ku kerygmatowi, stanowiącemu istotę orędzia chrześcijańskiego. ${ }^{7}$ Tego rodzaju zmiana nie doprowadziła jednak do odrzucenia czy zanegowania katechizmów, ale do zmiany ich struktury i treści. ${ }^{8}$

W późniejszej odnowie antropologicznej katechezy, inspirowanej impulsami II Soboru Watykańskiego, doktrynalne treści katechezy zaczęły być łączone z problemami życia człowieka. W treści katechezy pojawiły się tematy antropologiczne, interpretacja egzystencji,

Ch. W a c k e $\mathrm{n}$ h e i m, Breve storia della catechesi. Tradizione e novità, Bologna 1985, s. 39.

5 Por. W. O s i a 1, Historia katechizmu, s. 227-337; J. M o 1 i n a r i o, Le catéchisme, une invention moderne. De Luther à Benoît XVI, Montrouge 2013, s. 15-61.

6 Por. E. P a u 1, Deharbe Joseph (katecheza neoscholastyczna), w: K. M i s i a s z e k (red. wyd. pol.), Słownik katechetyczny, Warszawa 2007, s. 161-162.

7 Por. R. Mu r aw s k i, Kerygmatyczna odnowa katechezy, Studia katechetyczne 8/2012, s. 24.

8 Były to głównie katechizmy lokalne, które próbowały nadawać swojej treści bardziej kerygmatyczny charakter. Wyjątek stanowi słynny kerygmatyczny katechizm niemiecki z 1955 r., który miał dużo szersze oddziaływanie. Katechizm ten jako pierwszy odszedł od metody pytań i odpowiedzi; por. U. G i a n e t t o, Storia della redazione del CCC. Genere letterario, articolazione, linguaggio, destinatari, w: A. A m at a o, E. d a 1 C o v o lo, A. M. Tr i a c c a (red.), La catechesial traguardo. Studi sul Catechismo della Chiesa Cattolica, Roma 1997, s. 38-39. 
kwestie społeczne i polityczne, zaczęto szukać nowych form zbliżenia się do konkretnej sytuacji człowieka. Uwaga została przesunięta $\mathrm{z}$ treści katechezy ku jej odbiorcy. ${ }^{9}$ Podobnie jak w odnowie kerygmatycznej, tak i w tym przypadku katechizmy nie zostały odrzucone, a jedynie zaczęły zmieniać swoją treść. ${ }^{10}$

Podsumowując, należy jednak stwierdzić, że chociaż mamy do czynienia $\mathrm{z}$ długą tradycją katechizmowego nauczania, to jednak katechizm nie zawsze był jedynym i niczym niezastąpionym narzędziem formacji wiary. Nie było też jednego rodzaju katechizmu, gdyż funkcjonowały różne jego modele w zależności od adresatów i środowisk. Katechizm przyjmował tym samym różne funkcje, takie jak wtajemniczenie w wiarę, pouczenie w wierze, wprowadzenie w praktykę życia chrześcijańskiego czy obrona czystości i jedności wiary.

\section{Katechizm w dokumentach katechetycznych Kościoła}

Współczesna refleksja nad katechizmem przedstawia się równie bogato i interesująco. Z pewnością na pierwszym miejscu należy odnieść się do nauczania Kościoła zawartego w dokumentach katechetycznych. Stanowi ono punkt odniesienia do wszelkich dyskusji i poszukiwań.

Katechizm niezbędnym narzędziem katechezy

Dokumenty Kościoła wyraźnie wskazują na potrzebę katechizmu. Adhortacja Catechesi tradendae sięga bardzo daleko wstecz i przywołuje katechizm Soboru Trydenckiego. Stwierdza, że przyczynił

9 Por. R. M u r a w s k i, Etapy rozwoju katechezy, Ateneum kapłańskie 71/1978, s. 64-66; T. P a n u ś, Główne kierunki katechetyczne XX wieku, Kraków 2001, s. $83-94$.

10 Przykładem jest znany Katechizm holenderski dla dorosłych z 1966 r.; zob. U. G i a n e t t o, Katechizm holenderski, w: K. M i s i a s ze k (red. wyd. pol.), Stownik katechetyczny, s. 474-477. 
się on do odnowy pracy katechetycznej i pobudził duchownych do wykonywania obowiązku katechizacji. Chociaż nie postuluje się jego ponownego wprowadzenia, to jednak wyraża się życzenie, aby II Sobór Watykański mógł pobudzić dzisiejszą katechezę do podobnych inicjatyw. ${ }^{11}$

Wyrazem potrzeby katechizmu była publikacja Katechizmu Kościoła Katolickiego w 1992 r. W ogłoszonej z tej okazji konstytucji Fidei depositum stwierdza się, że katechizm jest „odpowiedzią na rzeczywistą potrzebę zarówno Kościoła powszechnego, jak i Kościołów partykularnych” i jako taki ,,przyczyni się w znacznym stopniu do odnowy całego życia kościelnego, której pragnął i którą zapoczątkował Sobór Watykański II". ${ }^{12}$ Katechizm powinien stać się również zachętą i pomocą do opracowania nowych katechizmów lokalnych. ${ }^{13}$

Dużo więcej uwagi potrzebie katechizmu poświęca Dyrektorium ogólne o katechizacji. Dokument przypomina, że „wśród wszystkich narzędzi katechetycznych najważniejsze miejsce zajmują katechizmy. Ich znaczenie wynika z faktu, że orędzie jakie przekazują, jest uznane za autentyczne i własne przez pasterzy Kościoła". ${ }^{14}$ Mówiąc o katechizmach, dokument omawia najpierw kwestię Katechizmu Kościoła Katolickiego z 1992 r., następnie zaś problem katechizmów lokalnych.

W odniesieniu do Katechizmu Kościoła Katolickiego pojawia się bardzo ważne przekonanie, że jego publikacja wnosi do katechezy

1 Por. Ja n Paw eł II, Adhortacja apostolska Catechesi tradendae, nr 13 (dalej: CT). Trzeba w tym miejscu dopowiedzieć, że II Sobór Watykański faktycznie pobudził do odnowy katechezy. Co prawda poświęcił mało miejsca samej katechezie i tym samym jeszcze mniej katechizmom, ale dzięki bogactwu swojej myśli teologicznej i pastoralnej sprawił, że w posoborowej myśli katechetycznej zaczęto rozróżniać między tekstem oficjalnym katechizmu i tekstami dydaktycznymi, dokonano biblijno-liturgicznej odnowy treści nauczania, zauważono potrzebę katechizmu dla dorosłych i zwrócono uwagę na konieczność inkulturacji w katechezie; por. U. G i a n e t t o, Storia della redazione del CCC, s. 40.

12 J a n P aw e 1 II, Konstytucja apostolska Fidei depositum, s. 6 (dalej: FD), w: Katechizm Kościoła Katolickiego, Poznań 1994, s. 5-9.

13 Tamże, s. 9.

14 Kongregacja d s. D u chowień s twa, Dyrektorium ogólne o katechizacji, Poznań 1997, nr 284 (dalej: DOK). 
„wielką tradycję katechizmów”. ${ }^{15}$ Podkreśla się tutaj poznawczy wymiar wiary (wymiar prawdziwościowy). Poucza się, że wiara „nie jest tylko przylgnięciem do Boga, ale także zgodą rozumu i woli na wiarę objawioną. Katechizmy zawsze przypominają Kościołowi potrzebę, aby wierni, chociażby w prostej formie, mieli organiczne poznanie wiary”. ${ }^{16}$ Stwierdza się, że „bogactwo tradycji patrystycznej i tradycji katechizmów ubogaca aktualną katechezę zarówno w jej koncepcji jak i w jej treściach". ${ }^{17}$

Odnośnie do katechizmów lokalnych Dyrektorium poucza, że stanowią one cenne narzędzie katechezy. ${ }^{18} \mathrm{Za}$ głosem adhortacji Catechesi tradendae wzywa się Konferencje Biskupów, aby podejmowały dzieło ich opracowania. ${ }^{19}$ Zostaje wyrażone piękne życzenie, aby Katechizm Kościoła Katolickiego i katechizmy lokalne stały się odnawiającym zaczynem katechezy w Kościele. ${ }^{20}$

Dokumenty Kościoła umiejscawiają konieczność katechizmów w szerszym kontekście potrzeby znajomości prawd wiary. Rezygnacja $\mathrm{z}$ doktryny uderza tak naprawdę w samą naturę katechezy. Katecheza, jak uczy adhortacja Catechesi tradendae, jest przecież „wychowywaniem w wierze dzieci, młodzieży i dorosłych, obejmuje przede wszystkim nauczanie doktryny chrześcijańskiej, przekazywane na ogół w sposób systematyczny i całościowy, dla wprowadzenia wierzących w pełnię życia chrześcijańskiego". ${ }^{21}$ Dyrektorium ogólne o katechizacji przypomina natomiast, że „ten, kto spotkał Chrystusa, pragnie poznać Go możliwie najbardziej, jak również pragnie poznać zamysł Ojca, który Go posłał. Poznanie treści wiary (fides quae) jest wymagane przez przylgnięcie do wiary (fides qua).

\footnotetext{
15 Tamże, nr 130.

16 Por. tamże.

17 Tamże.

18 Por. tamże, nr 131.

19 Por. tamże.

20 Por. tamże, $\mathrm{nr} 136$.

21 CT nr 18.
} 
Już w porządku ludzkim miłość do osoby prowadzi do chęci poznania go coraz bardziej”. ${ }^{22}$

Katechizm gwarancją przekazu prawdziwej nauki Kościoła

Dokumenty mocno podkreślają rolę katechizmów w zachowaniu wierności nauce Kościoła. Już Ogólna Instrukcja Katechetyczna z 1971 r. poucza, że celem katechizmów ma być wyrażenie w skondensowanej i praktycznej formie treści objawienia i tradycji chrześcijańskiej służących wychowaniu w wierze. Nakazuje się tym samym odrzucić wszelkie inne interpretacje wiary Kościoła, które są tylko prywatnymi hipotezami czy opiniami jakiejś szkoły teologicznej. Podaje się jednocześnie kilka ważnych kryteriów i wskazówek do właściwego opracowania katechizmów. ${ }^{23}$

W podobnym duchu wypowiada się adhortacja Catechesi tradendae i stwierdza, że przy opracowywaniu katechizmów koniecznie należy mieć aprobatę pasterzy i kierować się wytycznymi zawartymi w Ogólnej Instrukcji Katechetycznej. Jest apel, aby Konferencje Biskupie całego świata współdziałały ze Stolicą Apostolską w opracowywaniu dobrych katechizmów. ${ }^{24}$

Aspekt wierności nauce Kościoła powraca przy publikacji Katechizmu Kościoła Katolickiego w 1992 r. W konstytucji Fidei depositum stwierdza się, że katechizm jest wykładem wiary Kościoła i nauki katolickiej, które są poświadczone przez Pismo Święte, Tradycję Apostolską i Urząd Nauczycielski Kościoła i w ich świetle rozumiane. Uznaje się go za „pewną normę nauczania wiary, jak również za pożyteczne i właściwe narzędzie służące komunii eklezjalnej”. ${ }^{25}$

Także Dyrektorium ogólne o katechizacji przypomina, że celem katechizmów lokalnych jest zachowanie jedności wiary i wierności

\footnotetext{
22 DOK nr 85.

${ }^{23}$ Por. Kongrega c ja d s. D u chow i eń s t w a, Ogólna Instrukcja Katechetyczna, Warszawa 1971, nr 119.

24 Por. CT nr 50.

25 FD, s. 8.
} 
nauce katolickiej. Mają one mieć charakter oficjalny, być organiczną i podstawową syntezą wiary oraz należy je uważać wraz z Pismem Świętym za punkt odniesienia dla katechezy. ${ }^{26}$ Muszą być ponadto zgodne z Katechizmem Kościoła Katolickiego i uwzględniać normy i kryteria przekazu orędzia ewangelicznego nakreślone przez Ogólna Instrukcje Katechetyczna. ${ }^{27}$

Ta ortodoksyjna funkcja katechizmów, tak wyraziście podkreślana przez dokumenty Kościoła, ma swoje uzasadnienie w kontekście posoborowego rozwoju katechezy, kiedy pojawiły się podręczniki nie zawsze wiernie przekazujące naukę wiary. $Z$ tej też racji adhortacja Catechesi tradendae uważa katechizmy nie za jakieś proste środki dydaktyczne, ale za kompendia nauki wiary, których zadaniem jest zapewnienie wierności wierze katolickiej. ${ }^{28}$ Podręczniki uznaje się co prawda za jeden z ważniejszych sposobów odnowy katechetycznej i ,prawdziwy skarbiec dla dobra nauczania katechetycznego", ${ }^{29}$ ale zauważa się jednocześnie, że pojawiły się między nimi „publikacje wątpliwe i książki szkodliwe tak dla młodych, jak i dla życia samego Kościoła". ${ }^{30}$ Ich szkodliwość polega na tym, że, szukając odpowiedniejszego języka lub dostosowania się do najnowszych metod pedagogicznych, wprowadziły zamęt przez ,pomijanie świadome lub nieświadome istotnych elementów wiary Kościoła". 31

Dyrektorium ogólne o katechizacji wskazuje natomiast na potrzebę respektowania znanej zasady wierności Bogu i człowiekowi. Stwierdza, że chodzi o „umiejętność połączenia doskonałej wierności doktrynalnej z głębokim przystosowaniem do człowieka, przy uwzględnieniu psychologii wieku i kontekstu społeczno-kulturowego,

\footnotetext{
26 Por. DOK nr 132.

27 Por. tamże, nr 284.

28 Por. J. C h a r y t a ń s k i, Główne wątki Adhortacji Apostolskiej, w: W. K u b i k (red.), Katecheza po Soborze Watykańskim II w świetle dokumentów Kościoła, t. II, Warszawa 1985, s. 139-140.

${ }^{29}$ CT nr 49.

30 Tamże.

31 Por. tamie.
} 
w jakim on żyje". ${ }^{2}$ Polskie Dyrektorium katechetyczne widzi natomiast gwarancję poprawności podręczników w zachowaniu odpowiednich procedur ich zatwierdzania. ${ }^{33}$

Warto w tym miejscu przywołać opinię kard. Josepha Ratzingera wyrażoną podczas konferencji katechetycznych w Paryżu i w Lyonie w 1983 r. Według ówczesnego prefekta Kongregacji Nauki Wiary problem szkodliwych podręczników wynikał z błędu, jakim było „usunięcie katechizmu i stwierdzenie nieaktualności rodzaju literackiego katechizmu". ${ }^{34}$ Doprowadziło to do złej sytuacji, w której katecheza skoncentrowała się na różnych tekstach dydaktycznych, szukając dróg ich dostosowania do potrzeb słuchaczy. W wyniku tego nastąpiło „rozbicie głoszenia wiary na fragmenty. Głoszenie wiary nie tylko zostało w ten sposób zdane na arbitralność wykładu, ale poddano dyskusji pewne części wiary, które należą do jednej całości, a oddzielone od niej utraciły z nią związki". ${ }^{35}$ To zrodziło drugi problem. Powstała niebezpieczna sytuacja, w której katecheza zaczęła na ogół pomijać dogmat i dążyć do zrekonstruowania wiary, wychodząc bezpośrednio z Biblii. ${ }^{36}$ Zaczęto w ten sposób bardzo subiektywnie odczytywać prawdy wiary. Lekarstwem uzdrawiającym tę sytuację ma być - według kard. Ratzingera - powrót do klasycznego katechizmu. Za wzór katechizmu został przywołany katechizm Soboru Trydenckiego, który ma być punktem odniesienia do redagowania dzisiejszych katechizmów. Jego czteroczęściowa struktura, to znaczy Credo, liturgia, moralność i sakramenty, ,nie jest tylko jedną z możliwych dróg, ale należy ona do samej istoty katechezy". ${ }^{37}$ Niestety,

32 Por. DOK nr 283.

${ }_{33}$ Por. Konferencja Ep is k o pat u Polski,Dyrektorium katechetyczne Kościoła katolickiego w Polsce, Kraków 2001, nr 96 (dalej: PDK).

34 J. R a t z i nge r, Przekazywanie iźródła wiary, w: J. K ról i k ow s k i (wprow., tłum. i oprac.), Powstanie i znaczenie Katechizmu Kościoła Katolickiego w wypowiedziach Jana Pawła II i kardynała Josepha Ratzingera, Poznań 1997, s. 68 .

\footnotetext{
35 Tamże, s. 69.

36 Por. tamże, s. 70.

37 Tamże, s. 86.
} 
zauważa kard. Ratzinger, funkcjonujące dzisiaj katechizmy są raczej komentarzami, które przyćmiewają lub porzucają przywołaną powyżej treść katechezy. Brak dowartościowania katechizmu wobec mnożących się pomocy dydaktycznych rodzi dzisiaj „,ubóstwo nowej katechezy". ${ }^{38}$

Poglądy kard. Ratzingera wywołały liczne dyskusje w pismach i kręgach katechetycznych. Z jednej strony pojawiały się głosy podzielające niepokój o zatrzymanie procesu odnowy katechezy, z drugiej zaś obawiano się naruszenia integralności przekazu teologiczno-doktrynalnej treści katechezy. ${ }^{39}$

\section{Dostosowanie katechizmów do adresatów}

Dokumenty Kościoła w swojej trosce o wierność depozytowi wiary nie zapominają o konieczności dostosowania katechizmów do uwarunkowań ze strony adresatów. Adhortacja Catechesi tradendae, tak mocno akcentująca potrzebę wierności orędziu wiary, stwierdza jednocześnie, że katechizmy powinny być dostosowane metodycznie do potrzeb naszych czasów. ${ }^{40}$ Zapewne jest to wpływ wcześniejszego Synodu Biskupów z 1977 r., na którym mocno podkreślano potrzebę dostosowania katechizmów do poszczególnych grup odbiorców. ${ }^{41} \mathrm{Wy}-$ nikało to ze szczególnej wrażliwości debat synodalnych na problem relacji pomiędzy katechezą i kulturą. Temu zagadnieniu poświęcano

38 Tamże.

39 Według kard. J. T. Sancheza, ówczesnego Prefekta Kongregacji ds. Duchowieństwa, trwająca debata katechetyczna dotknęła tak naprawdę istoty samego pojęcia ,katechizmu”; por. J. T. S a n c h e z, Il catechismo della Chiesa Cattolica e la sua inculturazione nei Catechismi locali, w: Il Catechismo della Chiesa Cattolica. Dimensioni, caratteristiche, contenuti, Città del Vaticano 1993, s. 42-47

40 Por. CT nr 50.

41 Por. R. G i a c o m e 11 i, Quale catechesi Dossier Sinodo 1977, Leumann, Torino 1977 , s. 85. 
najwięcej uwagi zarówno podczas zgromadzeń ogólnych jak i w dyskusjach grup językowych. ${ }^{42}$

Najwięcej na temat dostosowań katechizmów mówi Dyrektorium ogólne o katechizacji. Czytamy w nim, że katechizmy lokalne mają być przystosowane do różnorakich kultur i środowisk. Ma to być realizacja „Bożej pedagogii”, jaką Bóg zastosował w swoim objawieniu, dostosowując swój język do natury człowieka ${ }^{43}$ Należy dokonywać „przystosowań, jakich wymagają zróżnicowania kultury, wieku, życia duchowego oraz sytuacji społecznych i eklezjalnych". ${ }^{4}$ Nie narzuca się konkretnej struktury czy artykulacji katechizmów. Zauważa się, że episkopaty publikują różne katechizmy (katechizmy o konfiguracji trynitarnej, oparte na etapach historii zbawienia itd.). Zachęca się do kreatywności także w odniesieniu do sformułowania samej treści. W przekazie doktryny należy być nie tylko wiernym orędziu chrześcijańskiemu, ale szukać też odpowiednich metod jego przekazu. ${ }^{45}$

\section{Współczesne wyzwania pod adresem katechizmu}

Współczesna sytuacja katechetyczna niesie wiele wyzwań dla nauczania katechizmu. To problem złożony, sygnalizowany już wcześniej, w którym z jednej strony trzeba uznać konieczność katechizmu, z drugiej zaś wyraźnie widać wiele trudności w jego nauczaniu.

42 A. Marranzini podaje, że temat inkulturacji był podjęty 41 razy na pierwszym etapie prac synodalnych, dyskutowano o nim we wszystkich grupach językowych i w 9 późniejszych wystąpieniach; por. A. M a r r a n z i n i, I Giovani al V Sinodo dei Vescovi, Roma 1978, s. 49. Powyższe dane potwierdza również schemat graficzny wystąpień synodalnych sporządzony przez E. F r a n c h i n i, Catechesi come „plantatio ecclesiale”, Il Regno-attualità 22(1977)20, s. 447.

43 Por. DOK nr 131.

44 Tamże, nr 133. Dyrektorium nakazuje dokonać jeszcze innego rozróżnienia między „katechizmem, który przystosowuje orędzie chrześcijańskie do różnego wieku, sytuacji i kultur, a tym, co jest czystą syntezą Katechizmu Kościoła Katolickiego jako instrumentu wprowadzającego do jego studium. Są to dwa różne rodzaje literackie"; tamże, nr 135.

45 Por. tamże. 
Katechizm wobec wyzwań ewangelizacji

Z pewnością wszelkie trudności w nauczaniu katechizmu należy rozpatrywać przede wszystkim w kontekście ogólnego kryzysu religijności człowieka. Zjawisko to ma różne przyczyny i oblicza, które wpisują się w kontekst dzisiejszej kultury postmodernizmu, negatywnie oddziałującej na wiarę człowieka w różnych jej wymiarach. Słuszne wydają się opinie, że w obecnej sytuacji trzeba raczej na nowo ewangelizować niż nauczać katechizmu, gdyż dzisiejsi adresaci katechezy wymagają przede wszystkim ewangelizacyjnego głoszenia Ewangelii w celu ożywienia ich wiary. $Z$ tej też racji formułuje się dzisiaj także nowy paradygmat katechezy, według którego powinna stać się ona mniej doktrynalna a bardziej ewangelizacyjna. ${ }^{46}$

Nie dziwi fakt, że w obliczu takiej sytuacji katechizm jest postrzegany przez niektórych jako narzędzie mało skuteczne i niewystarczające ${ }^{47}$ Oczywiście temat ewangelizacji jest jak najbardziej aktualny, ale nie powinien on całkowicie negować potrzeby katechizmu. Być może zamiast odrzucać katechizm należałoby mu nadać bardziej ewangelizacyjny charakter? Chodzi o to, aby nie był to przekaz suchej i trudnej do zrozumienia doktryny, ale nauczanie z odniesieniem do życia i problemów człowieka. Należy stawiać pytania o sens życia i wykazywać, że znajdują one odpowiedzi w wierze Kościoła. Konieczne są interesujące zapytania, które będą rodzić chęć sięgnięcia po katechizm.

Odnosi się ponadto wrażenie, że ze względu na ewangelizacyjne wyzwania we współczesnej refleksji katechetycznej zaniedbuje się nauczanie doktryny wiary. Należy być tutaj roztropnym i nie ograniczać się do wołania o ewangelizację, gdyż jest jeszcze przecież

46 Por. E. A 1 b e r i c h, Na 50-lecie „Katechety”. W poszukiwaniu nowego „paradygmatu katechetyki”. Refleksje nad sytuacja katechezy w Europie, w: Między tradycją a współczesnościq̨. I Krajowy Kongres Katechetyczny, Poznań 2008, s. 91-103; t e n ż e, Un nuovo paradigma per la catechesi. Istanze e prospettive catechetiche in un recente convegno parigino, Catechesi 72(2003)4, s. 3-9.

47 Por. G. B i a n c a r d i, Il testo di catechismo. Quale posto nella nuova evangelizzazione? Credere oggi 32(2012)5, s. 84-85. 
stosunkowo duża grupa ludzi, którzy wierzą, i chociaż nie praktykują systematycznie, to jednak oczekują solidnego pouczenia w wierze. Oni nie chcą, aby mówić im o nawróceniu, natomiast chcieliby otrzymać mądry i zrozumiały wykład nauki Kościoła.

\section{Wiara zamiast wiedzy?}

Wydaje się, że nauczanie katechizmu zostaje bardzo mocno osłabione nowym typem religijności człowieka, w której za ważniejszą uważa się samą postawę wiary (fides qua) niż wiedzę o wierze (fide quae). Twierdzi się, że dużo wartościowsza jest osobista więź z Bogiem niż często niezrozumiała i trudna doktryna. Podważa się tym samym konieczność poznawania nauki wiary i nie wykazuje się żadnego zainteresowania nią. To owoc przemian religijnych, w których, według J. Mariańskiego, religia wiąże się „,bardziej z doświadczeniem religijnym niż nauczaniem kościelnym, bardziej z tym co osobiste niż instytucjonalne, bardziej z religijnością prywatną niż oficjalną". ${ }^{48}$

Nie wolno rezygnować z nauczania katechizmu, ale pouczać i uświadamiać, że do właściwego spojrzenia na Boga, wiarę i Kościół konieczna jest znajomość wiary. Warto przywołać cenne pouczenie Benedykta XVI, według którego „katecheza nie jest głównie kwestią metody, lecz treści, na co wskazuje sama jej nazwa - chodzi o takie wewnętrzne przyjęcie (kat-echein) całości chrześcijańskiego objawienia, które dla ludzkich serc i umysłów może uczynić zrozumiałym słowo Tego, który oddał za nas życie". ${ }^{49}$ Należy w tym celu ukazywać potrzebę i wartość prawd wiary. Jest to niezwykle ważne zadanie dla dzisiejszej katechezy. ${ }^{50}$

48 J. M a r i a ń s k i, Religijność spoleczeństwa polskiego w perspektywie europejskiej. Próba syntezy socjologicznej, Kraków 2004, s. 176.

49 B e n e d y k t XVI, Trzeba, by każdy czut sięw Kościele jak u siebie. Spotkanie z Konferencja Episkopatu Francji, L'Osservatore Romano, wyd. pol. 29(2008)10-11, s. 32 .

50 Por. G. B i a n c a r d i, Il testo di catechismo, s. 91-92; G. C a s a r o t t o, Esperienza e dottrina nella catechesi. Risonanze di un recente dibattito, Catechesi 83(2013-2014)4, s. 74-79. 
Z drugiej jednak strony należy podkreślić, że katecheza, jakkolwiek polega na nauczaniu doktryny, to jednak nie może być ograniczana do jej przekazu, czy być z nią utożsamiana. Tego rodzaju sytuacja prowadziłaby do odejścia od zasadniczego celu katechezy, jakim jest doprowadzenie do zjednoczenia z Chrystusem. ${ }^{51}$ Kiedy więc uznaje się konieczność doktryny to zawsze z zastrzeżeniem, że posiada ona charakter służebny wobec wiary. Wynika to z prawdy, że „głównym celem nauczania katechetycznego jest kształtowanie wiary". ${ }^{52}$ Zapomnienie tej prawdy rodzi niebezpieczeństwo intelektualizmu i wypaczenia samej natury katechezy, co prowadzi do postawy indoktrynacji czy też nawet odrzucenia przekazywanej nauki.

Katechizm a kryzys znajomości prawd wiary

Konieczność zwrócenia większej uwagi na katechizm wynika też z niepokojącego poziomu znajomości prawd wiary. Zapewne jest to skutek negacji potrzeby poznania doktryny, o której była mowa powyżej. Jesteśmy świadkami wysokiego poziomu ignorancji religijnej, zarówno wśród osób dorosłych jak i ludzi młodych. Wierni ukazują poważne braki wiedzy na temat Credo, rozumienia celebracji mszy św., znajomości podstawowych modlitw czy wiedzy na temat elementarnych zasad moralności chrześcijańskiej. Świadectwem analfabetyzmu wśród młodzieży mogą być ciekawe refleksje zawarte przed dwu laty w jednym z numerów „Katechety”. ${ }^{33}$ Stwierdza się w nich m.in., że ,wiedza religijna gimnazjalistów jest na poziomie klas dzieci pierwszokomunijnych", ${ }^{54}$ natomiast uczniowie szkół ponadgimnazjalnych nie potrafią wymienić poprawnie wszystkich sakramentów świętych czy też imion ewangelistów. ${ }^{55}$

51 Por. CT nr 5.

52 PDK nr 44.

53 Por. Katecheta 57(2013)7-8.

54 I. M a t u s z e w s k a, Analfabetyzm religijny współczesnej młodzieży gimnazjalnej, Katecheta 57(2013)7-8, s. 92.

55 Por. A. Z e $11 \mathrm{~m}$ a, Analfabetyzm religijny polskiej młodzieży wyzwaniem dla szkolnego nauczania religii, Katecheta 57(2013)7-8, s. 7. 
Z pewnością temat ignorancji religijnej jest złożony i uwarunkowany wieloma czynnikami, chociażby wspomnianymi przemianami kulturowymi i religijnymi naszych czasów, ale nie można wykluczyć czynnika katechetycznego. Sytuacja dużej ignorancji religijnej nie może pominąć pytania o skuteczność lekcji religii.

Wydaje się również, że wiele dzisiejszych postaw i zachowań katolików kontestujących naukę Kościoła wynika m.in. z braku jej zrozumienia czy też po prostu z braku jej znajomości. Oczywiście nie jest to jedyny czynnik uzasadniający te negatywne zachowania, ale w niektórych przypadkach okazuje się on znaczący. Wielu katechetów potwierdza sytuacje, w których negatywne postawy odrzucania czy podważania nauki Kościoła zostały pokonywane i rozwiązane na drodze spokojnego i rzeczowego jej wyjaśnienia.

W takim duchu należy odczytywać wołanie Kościoła o należne wykorzystanie katechizmów. Kościół apelował o powrót do Katechizmu Kościoła Katolickiego w niedawnym Roku Wiary. ${ }^{56}$ Znaczącym momentem było opracowanie Kompendium Katechizmu Kościoła Katolickiego w 2005 r. Innym znakiem jest Katechizm Kościoła Katolickiego dla młodych Youcat z 2011 r. Benedykt XVI przekazał go młodzieży w roku Światowego Dnia Młodzieży w Madrycie. Pojawiają się też inicjatywy lokalne, diecezjalne, mające na celu nauczanie katechizmu. Przykładem może być opracowanie w diecezji płockiej tzw. Katechizmu Płockiego. Katechizm polegał na wygłaszaniu krótkich katechez na temat poszczególnych prawd wiary. Katechezy miały miejsce przed każdą niedzielną Eucharystią, w diecezjalnym radiu i w edycji płockiej tygodnika „Niedziela”. ${ }^{57}$

56 Por. B e n e d y k t XVI, List apostolski w formie motu proprio „Porta fidei” ogłaszający Rok Wiary, Kraków 2012, nr 11-12.

57 Por. Katechizm płocki, cz. I: Wyznanie wiary, Płock 2008; cz. II: Celebracja misterium chrześcijańskiego, Płock 2009; cz. III: Życie w Chrystusie, Płock 2011; cz. IV: Modlitwa chrześcijańska, Płock 2011. 
Wyzwanie krytycznej i naukowej mentalności człowieka

Warto przywołać jeszcze inny problem związany z potrzebą odwoływania się do katechizmu. Chodzi o zagadnienie współczesnej mentalności człowieka, która jest bardzo krytyczna i szuka głębszego poznania tego, w co się wierzy. Dzisiejszy człowiek, dzięki współczesnym środkom komunikacji, szczególnie Internetu, otrzymuje dużo informacji, które pozwalają mu szerzej i krytyczniej patrzeć na sprawy wiary. Coraz mniej ludzi chce wierzyć bezkrytycznie, a coraz więcej szuka uzasadnienia dla swojej wiary. Dlatego też nie wystarczy dzisiaj tylko mówić, że trzeba wierzyć, ale trzeba przede wszystkim mądrze o tej wierze mówić. Takiemu rzeczowemu mówieniu o wierze służy właśnie katechizm. Dzięki niemu możemy przekazywać solidną wiedzę, do której prawo mają uczniowie. Jeśli katecheta nie potrafi mówić rzeczowo na konkretny temat, to nic dziwnego, że często jego nauka spotyka się z odrzuceniem i dezaprobatą.

\section{Problem pamięciowego uczenia się katechizmu}

Trudnością w nauczaniu katechizmu może być niechęć do uczenia się na pamięć katechetycznych formuł wiary. Adhortacja Catechesi tradendae wymienia wśród nich słowa Jezusa, ważne teksty biblijne, Dekalog, formuły wyznania wiary, teksty liturgiczne, ważniejsze modlitwy, główne prawdy nauki chrześcijańskiej..$^{58}$ Katechizmy, ucząc tych formuł, przyjmują często mechanizm pytań i odpowiedzi. W opinii wielu dzisiejszych katechizowanych formuły te są zbyt trudne, mało zrozumiałe i niepotrzebne. Tego rodzaju przekonania pojawiły się też w posoborowym rozwoju katechezy, w wyniku czego w niektórych miejscach zaniechano długotrwałej tradycji i prawie całkowicie usunięto z katechizacji ćwiczenia pamięciowe. ${ }^{59}$

Nie wolno zrezygnować z pamięciowego nauczania tych formul, ale trzeba szukać dróg ich integracji z formacją wewnętrznego

\footnotetext{
58 Por. CT nr 55.

59 Por. tamie.
} 
rozwoju wiary. Przede wszystkim należy mądrze ukazywać ich potrzebę. Jan Paweł II w adhortacji Catechesi tradendae pięknie poucza, że „kwiaty wiary i pobożności - jeśli można się tak wyrazić - nie wzrastają w miejscach pustynnych katechizacji nie posługującej się pamięcią". ${ }^{60}$ Pozytywnym przykładem przekazu formuł mogą być wysiłki podejmowane przez dzisiejsze katechizmy, które nabierają bardziej charakteru narracyjnego i objaśniającego. Ta zmiana wynika nie tylko z powodów pedagogicznych, ale z samej struktury orędzia chrześcijańskiego. ${ }^{61}$

Ponadto ważne jest wskazanie polskiego Dyrektorium katechetycznego, według którego ,autorzy programów i podręczników katechetycznych winni wyodrębnić proponowane formuły przeznaczone do memoryzacji. Należy jednakże pamiętać, że memoryzacja, aczkolwiek ważna i potrzebna, nie może wyprzeć innych metod przyswajania przez katechizowanych treści wiary". ${ }^{2}$

Katechizm przestarzałym czy aktualnym narzędziem katechezy?

Tak sformułowane pytanie podsumowuje niejako całość dokonanej refleksji. Jak zostało wykazane, różne są poglądy na temat katechizmu. Dokumenty Kościoła wskazują na jego konieczność. Słyszy się też przekonania, że katechizm może być postrzegany tylko jako jedno z możliwych narzędzi katechezy, którego jednak nie można absolutyzować czy narzucać. ${ }^{63}$ Pojawiają się wreszcie opinie negujące przydatność katechizmu. Ich echem są sytuacje, kiedy po II Soborze Watykańskim w niektórych krajach Europy zaczęto wprowadzać w miejsce katechizmu inne pomoce, uważane za bardziej odpowiednie do zmieniających się uwarunkowań i potrzeb

60 Tamże.

${ }_{61}$ Por. U. G i a n e t t o, Formuly katechetyczne, w: K. M i s i a s z e k (red. wyd. pol.), Stownik katechetyczny, s. 271.

${ }^{62}$ PDK nr 46.

63 Por. E. A $1 \mathrm{~b}$ e $\mathrm{r}$ i c h, La questione del catechismo: uno sguardo al passato e prospettive di avvenire, s. 9. 
odbiorców. Przybierały one postać różnorodnych podstaw programowych, zbiorów dokumentów czy tekstów i pomocy dydaktycznych. ${ }^{64}$

Wobec tych różnych opinii i stanowisk należy przyjąć wskazania podane przez dokumenty Kościoła. Przede wszystkim katechizm zachowuje swoją aktualność i nie wolno z niego zrezygnować. $Z$ pewnością nie jest łatwym narzędziem dla dzisiejszej katechezy. Wydaje się, że w pokonywaniu trudności w jego wykorzystaniu mogą być pomocne dwie wskazówki. Po pierwsze katechizmy muszą uwzględniać najważniejsze kryteria katechetyczne, teologiczne i pedagogiczne To złożony i wielowymiarowy proces odczytywania katechizmu w świetle wyzwań płynących ze strony Kościoła, kultury i człowieka. ${ }^{65} \mathrm{~W}$ zakresie kryteriów katechetycznych należy pytać o realizację podstawowych funkcji katechezy. Katechizm nie może się dzisiaj ograniczać do przekazu wiedzy religijnej. Musi podejmować również inne funkcje, szczególnie funkcję ewangelizacyjną. W przypadku kryteriów teologicznych powinno się umiejętnie odwoływać do Tradycji Kościoła i źródeł wiary. Dotykamy tutaj ważnej kwestii inkulturacji treści wiary. Równie potrzebne są wreszcie kryteria pedagogiczne i metodyczne. Katechizmy trzeba dostosować do uwarunkowań adresatów odnośnie do ich wieku, zdolności, stopnia religijności czy problemów życia. Szczególnej uwadze należy poddać język katechizmów, uczynić go ciekawym i zrozumiałym.

Drugi obszar poszukiwań dotyczy kreatywności i inteligencji samego katechety. Jest prawdą, że doktrynalne treści katechizmów nie zawsze wzbudzają zainteresowanie i są łatwe do nauczania, ale trzeba pytać się, czy poświęca się dostatecznie dużo siły i czasu dla

${ }^{64}$ Przykładem mogą być takie kraje jak Francja, Holandia czy Niemcy; por. tamże, s. 5; t e n ż e, Le fonti della catechesi e il ruolo dei catechismi, w: E. A 1 b e$\mathrm{r}$ i c h, U. G i a n e t t o (red.), Andate e insegnate. Manuale di catechetica, Leumann, Torino 2002, s. 100; G. A n g e 1 in i, La catechesi dal Vaticano II a oggi. Analisi storica per chiarire i problemi e le linee della catechesi ai giorni nostri, w: Catechisti Testimoni. Atti del IV Convegno Catechistico Diocesano (Busto Arsizio 30. sett - 6 ott 1984), Besana Brianza, Milano 1985, s. 49-85.

${ }_{65}$ Por. J. J o n c h e r a y, Quale „,catechismo” per quale „mondo”? Concilium 25/1989, s. 606. 
znalezienia ciekawych metod ich przekazu? Czy próbuje się wykorzystywać katechizmy w interesujący i zrozumiały sposób? Nauka doktryny winna dokonywać się w ścisłym powiązaniu z pytaniami, zainteresowaniami i problemami życia człowieka. Osoba katechizowana musi postrzegać treść wiary jako światło na drodze życia.

$$
* * *
$$

Historia katechezy jak i czasy współczesne pokazują, że katechizm zajmuje ważne miejsce w katechetycznej posłudze słowa Bożego w Kościele. Z pewnością nie uniknie się sporów i dyskusji nad jego miejscem i rolą w procesie formacji wiary. Im więcej jednak dyskusji, tym lepiej dla samego katechizmu. To szansa do wspólnej i twórczej refleksji, aby katechizm mógł stać się owocnym narzędziem we współczesnych czasach nowej ewangelizacji.

bp Wojciech OSIAL

Słowa kluczowe: wiara chrześcijańska, katecheza, katechizm, dokumenty Kościoła katolickiego

Keywords: Christian faith, catechesis, catechism, documents of Catholic Church

\section{Catechism as a Tool of Doctrinal Catechesis - The Riches of Tradition towards Challenges of Contemporary Times Summary}

The article is an attempt to show the most important questions concerning the use of catechism in contemporary catechesis. Special attention is focused on the necessity of catechism in religious education, but the author also describes the difficulties related to the teaching of this catechism. This theme is first analyzed in the light of history and catechetical documents. The first part of the reflection is a historical review of catechism contained in catechesis. In the second part the author analyzes the most important 
documents for catechesis and searches in them contents about the problem of catechism in catechesis: the General Catechetical Directory of 1971, the Apostolic Exhortation Catechesi tradendae of 1979, the General Directory for Catechesis of 1997 and the Directory for Catechesis of the Catholic Church in Poland of 2001. In the third part one finds the analyses of the most important problems concerning the use of catechism in the practice of catechesis. The following challenges of the new evangelization are pointed out: a crisis of the faith and a problem concerning the knowledge of Christian doctrine, tension between the knowledge of faith and the attitude of faith, and refusal to memorize the catechism formulas. 